\title{
Market representations in industrial markerting: Could representations influence strategy?
}

\author{
Carlos Diaz Ruiz and Christian Kowalkowski
}

\section{Linköping University Post Print}

\section{Tweet}

N.B.: When citing this work, cite the original article.

Original Publication:

Carlos Diaz Ruiz and Christian Kowalkowski, Market representations in industrial markerting: Could representations influence strategy? 2014, Industrial Marketing Management, (43), 6, 1026-1034.

http://dx.doi.org/10.1016/i.indmarman.2014.05.015

Copyright: Elsevier http://www.elsevier.com/

Postprint available at: Linköping University Electronic Press

http://urn.kb.se/resolve?urn=urn:nbn:se:liu:diva-106908 


\title{
Market representations in industrial marketing: Could representations influence
} strategy?

\author{
Carlos A. Diaz Ruiz ${ }^{a, *}$ \\ Christian Kowalkowski a,b
}

${ }^{\text {a }}$ Department of Marketing, CERS — Centre for Relationship Marketing and Service Management, Hanken School of Economics, PO Box 479, FIN-00101 Helsinki, Finland.

${ }^{\mathrm{b}}$ Department of Management and Engineering, Linköping University, SE-581 83 Linköping, Sweden

* Corresponding author. Corresponding author at: Department of Marketing, CERS - Centre for Relationship Marketing and Service Management, Hanken School of Economics, PO Box 479, FIN-00101 Helsinki, Finland. Tel.: +358 9431 331; fax: +358 943133287.

Email addresses carlos.diazruiz@hanken.fi (C.A. Diaz Ruiz), christian.kowalkowski@hanken.fi (C. Kowalkowski). 


\section{Research highlights}

- The paper shows that the form in which the external environment of a firm is represented influences the marketing strategy.

- A product differentiation strategy is more likely to be adopted when market representations are indicative and stable; this contrasts to a service focus strategy, which is more likely to be chosen when market representations are destabilizing and dynamic.

- Managers benefit from understanding how representations affect the way they understand their markets, and how these market representations influence their decisions.

- The study shows how quasi experiments can support case study research and replicate findings in marketing research.

- A key methodological contribution is the use of representations as treatments in quasi experiments.

\section{Biographical sketches}

Carlos A. Diaz Ruiz is a PhD marketing student at the Centre for Relationship Marketing and Service Management at Hanken School of Economics (www.hanken.fi), Finland. He is currently conducting research on market representations, performativity, and assemblages in marketing and has published articles in Marketing Theory and The Marketing Review. As a practitioner, he served as regional head of marketing communications for an airline, as well as a market research consultant in Latin America.

Christian Kowalkowski is assistant professor of marketing at the Centre for Relationship Marketing and Service Management at Hanken School of Economics, Finland. Dr. Kowalkowski also holds a part-time position as associate professor of industrial marketing at Linköping University, Sweden. He is currently conducting research on service infusion in manufacturing, relationship dynamics, service innovation, and solutions marketing. He serves as editorial board member of Industrial Marketing Management and has published articles in journals such as European Journal of Marketing, Industrial Marketing Management, Journal of Business Research, Journal of Business \& Industrial Marketing, and Journal of Businessto-Business Marketing. 


\title{
Market representations in industrial marketing: Could representations influence
}

\section{strategy?}

\begin{abstract}
A central question in industrial marketing is whether the form in which the external environment of a firm is represented influences the marketing strategy. This influence has been studied generally through case study research, and quantitative evidence is limited. In response to this limitation, this paper reports on a quasi-experiment investigating whether market representations have a constructive aspect in business. Empirically, this study compares two types of ostensive and performative market representations—service focus and product differentiation - in order to test for influence exacted by industrial marketing on strategies. Results indicate that service focus is selected when market representations rely on agency in firms (i.e., performative), and product strategies are selected when structures are emphasized (i.e., ostensive). This paper contributes to methodology development by expanding the link between a case study approach and quasi-experiments explaining how quasi-experiments can replicate findings in industrial marketing.
\end{abstract}

\section{Keywords}

Market representations, quasi-experiment, business case, marketing strategy, decisionmaking, methodology development 


\section{Introduction}

Marketing is a representational practice (Levy, 1959; Stern, 2004). Marketers operate by representing one thing with something else-for example, using a brand to represent the values of the company, or crafting ads to represent the benefits of a product. The importance of representation has been at the forefront of marketing thought since as early as the $1950 \mathrm{~s}$ (Gardner and Levy, 1955), yet general consensus is that only marketers utilize representations to their advantage. As such, scholars observe how marketers craft brands to mean something, and how advertisers use ads to persuade. Marketing literature often overlooks the fact that marketers are, in a sense, themselves the subject of representations (Stern, 2004).

Representations affect the form in which managers understand their business market - that is, how it is represented in their minds - constraining their repertoire of managerial actions (Hagel, Brown and Davison, 2008).

Market representations are coherent yet simplified views of what a market is and how it works. Managers need representations because markets are generally too complex, involving multiple people conducting multiple trades, at separate times, at multiple locations, and for various reasons (Deshpande and Zaltman, 1982). The concept of the market is complicated by the legacy of a physical place where buyers and sellers physically convened to trade (i.e., a marketplace), but this meaning is no longer accurate (Callon, 1998). Rather, contemporary markets involve heterogeneous associations among humans, materials, and signs (Kjellberg and Helgesson, 2006). Managers use representations to impose order on these complex environments by isolating points of competitive advantage (Day and Nedungadi, 1994) and thus, the manner in which market complexity is simplified results in a market representation. However, it remains unclear whether market representations have any effect on management.

Literature in managerial representations argues that the manner in which managers simplify the complexity of their external environment affects how firms conduct business (Grazzini, 2013). In other words, representations of a firm's external environment impact firm strategy (Storbacka and Nenonen, 2011; Harrison and Kjellberg, 2010). Drawing on their expertise as business consultants, Storbacka and Nenonen (2011) argued that how firms understand their markets is critical not only for achieving more efficient operations, but also for effectively shaping their business environments. Harrison and Kjellberg (2010) found that how industrial firms understand their markets influences crucial business decisions. For example, consider one firm that conceives its markets based on relationships within a 
network (long-term or short-term), and one that understands its markets based on profitability (high or low). These differing conceptions may contribute to very different business decisions between these firms; for example, the firm that views its market through the lens of relationships is more likely to give preference to a long-term relationship over short-term profitability.

Scholars suggesting that representations influence marketing strategies rely on case studies (e.g., Rinallo and Golfetto, 2006; Harrison and Kjellberg, 2010), because quantitative evidence is largely unavailable. However, quantitative evidence can be useful for isolating context (Chandler and Vargo, 2011) and cognition (Grazzini, 2013). An unanswered question in industrial marketing is whether market representations constrain managerial options-and thus, whether market representations influence business marketing strategy. In consequence, the purpose of this paper is to isolate market representations and test whether the manner in which the external environment of firms is represented influences marketing strategies.

The contributions of this paper are both conceptual and methodological. The conceptual contribution demonstrates that market representations are constructive. The methodological contribution introduces quasi-experiments to support findings of case studies. A quasi-experiment involves the manipulation of quasi-independent treatments tests for effects in a controlled environment (Campbell and Stanley, 1963). To detail, this study tests whether certain types of market representations lead more to service focus strategies, or to product differentiation strategies. We conducted a quasi-experiment on 143 graduate marketing students as proxies for marketing managers, using an industrial business case. The case was manipulated to include two types of market representations: ostensive, which separates the market from the firm, and performative, which integrate the capabilities of an organization. Results indicate that a service focus strategy is more likely when market representations are performative, and that a product differentiation strategy is more likely when market representations are ostensive.

The paper is organized as follows. Following this introduction, Section 2 introduces the conceptual anchor of the study in the form of market representations. Section 3 frames the conceptual aspect of the study by identifying marketing strategies as the variable, and market representations as treatment. Section 4 introduces the method of study and crafts hypotheses derived from the conceptual anchor. Section 5 discusses conceptual, methodological, and 
managerial implications, and limitations and future research, leading into the conclusion in Section 6.

\section{Market representations}

In order to understand a firm's market context, managers must make assumptions and predictions about significant external structures. Furthermore, managers must simplify and isolate relevant issues involving complicated interactions between social, economic, political, and technological structures (Deshpande and Zaltman, 1982); in order to make simplifications about markets, they have to assemble representations. A representation is a human-made construct that stands for, and yet is independent from, reality. Representations are frequently used in applied social disciplines like cartography, in which distortions occur as a result of representing the Earth, a three-dimensional object, on a two-dimensional surface. What cartographers discuss is not whether distortions should occur at all, but rather which distortions are acceptable for achieving certain purposes. A map used to establish geopolitical boundaries is different from a map charting navigation on the sea. In marketing, however, Stern (2004) argued that more debate is centered on the object of representations - that is, the phenomenon of interest in markets - than on the manner in which market phenomena are represented.

A market representation is defined here as coherent yet incomplete view of what a market is and how it works, either at the time present or in an alternative future. Managers sort out and select from direct observation, personal experiences, and secondary data the elements that constitute a self-reinforcing view (Day and Nedungadi, 1994). Because of the constructive aspect of market representations (Harrison and Kjellberg, 2010), managers can extrapolate divisions in their own organization into market representations: A firm could divide its market in two regions (e.g., the US and the rest of the world) for the only reason that the sales department in the organization is divided in such manner. Market representations include "the representational objects (what) and the practices in which objects are put together (how), in order to privilege a view of a market (what for)" (Diaz Ruiz, 2013), and thus, multiple versions of markets can exist in a representation. Some examples include representing a market following geographic boundaries (e.g., China is a market); framing a market corresponding to a product category (e.g., the market of smartphones); and imagining practices at the center of markets (e.g., online gambling as a market). 
The forefront of conceptualizing multiple versions of markets can be found in industrial marketing research (e.g. Hagberg and Kjellberg, 2010; Finch and Geiger, 2011; Azimont and Araujo, 2007; 2010). Overall, industrial markets seem harder to categorize into the wellknown structures of competition, supply and demand (Ford and Håkansson, 2006; Håkansson and Ford, 2002). Market conceptualizations developed by IMP scholars (e.g., markets as networks; McLoughlin and Horan, 2002) have convincingly demonstrated that multiple versions of markets can be found. By conceptualizing industrial markets more fully, firms have access to a wider repertoire of resources than previously acknowledged. For instance, research has explained how fashion firms used trade shows to steer market trends (Rinallo and Golfetto, 2006), how manufacturers used meetings for category management with retailers to influence boundaries among product categories (Azimont and Araujo, 2007), and how independent firms solve problems jointly (Aarikka-Stenroos and Jaakkola, 2012; Biggemann et al., 2013).

However, the idea that managers simplify the complexity of markets in multiple ways is generally not acknowledged in literature. The question of how individual managers understand their environments is of little relevance when self-seeking economic rationality is emphasized, because as the story goes, managers should converge on optimal decisions, given that managers act as rational self-interest maximizers (cf. Ghoshal, 2005). Economic rationality assumes that managers know their environment and act under similar maximizing principles, and therefore considers understanding how managers represent markets seems inconsequential. Despite increasing attention on deviations from rationality in human behavior, marketing literature has a strong legacy of economic rationality (Varey, 2010), and therefore, important contributions - including how markets are constituted via networks (McLoughlin and Horan, 2002), or how intuition influences management (Vanharanta and Easton, 2010) — are yet to be fully incorporated into mainstream marketing research.

Business scholars have presented convincing arguments that managers use a form of bounded rationality and selected issues from their markets in order to make business decisions. Business cases report that the selection of these important issues influences the type of strategy that firms follow (Harrison, 2012). Nevertheless, we do not know which kind of representation leads to which kind of strategy, in part because neither representations nor strategies have been properly codified, and because marketing research lacks a method for integrating representations identified in case studies for quantitative validation. The following section discusses how a customized method integrating quasi-experiments and narratives 
derived from case studies, as well as other findings originating from industrial marketing, could be useful for the study of market representations.

\section{Constructing the study: Could market representations influence business marketing strategy?}

This section anchors the conceptual part of the study that identifies whether a theoretical cause-effect relationship could exist between market representations (i.e., treatment) and business-marketing strategy (i.e., variable of interest).

\subsection{Market representations: Performative vs. ostensive market representations}

This section argues that two types of market representations are distinct enough to constitute independent representations. The typology of market representations in Table 1 corresponds to the duality of structure and action: ostensive and performative (Diaz Ruiz, 2013; Harrison, 2012).

Insert Table 1 around here

Market representations are ostensive when concise and descriptive snippets encapsulate defining aspects of the market. Ostensive representations focus particularly on structures and patterns constraining options, and thus focus on how firms react to external constraints. An ostensive definition conveys meanings by exhibiting instances of the term; for example, "that is the color red" (Wittgenstein, 2001). Explanations are normally detached, and thus representations can be qualified and contested; for example, "that is not the color red." An ostensive representation treats the market as independent from the firm, and thus is crafted as a structure constraining options. This view is influenced by determinism of institutional analysis of organizations (Ghoshal, 2005), and it relates to Porter's (1985) traditional view of markets - such as the Five Forces Model, wherein companies compete in predefined markets.

Market representations are performative when dynamic and instrumental accounts focus on the capabilities of firms. An emphasis on agency treats the environment as moldable, and thus focuses on potentially disruptive actions. When managers request actionable information 
(Bernhardt, 1994), they are asking for performative representations. Performative representations envision a potentially different state of affairs and focus on the means for the firm to enact that version into reality, for instance, by seizing resources or exploiting weaknesses. Performative definitions aim to change what is described (Austin, 1975), and thus cannot be qualified as true or false. This view falls more in line with resource-based and competence-based views, whereby firms take action based on what competences, resources, and skills they can utilize (e.g., Peteraf, 1993). One well-known example is Prahalad and Hamel's (1990) example of Honda's entry (and market-shaping effects) on the U.S. car market through world-class engines.

\subsection{Business marketing strategies: Product differentiation vs. service focus strategies}

The overall question of this study is whether market representations influence strategy. In order to test that question, the dependent variable in the study is the selection of a marketing strategy. The selection draws from the important discussion concerning service focus in manufacturing firms (Fang, Palmatier, and Steenkamp, 2008; Kindström and Kowalkowski, 2014). Although service focus implies increased relative importance of service, the marketing strategies behind service focus may differ (Gebauer, 2008; Raddats and Easingwood, 2010). This study distinguishes two types of marketing strategies: product differentiation, whereby the product portfolio is used to protect or enhance the traditional product business; and service focus, whereby a distinct services business is developed independently from the traditional product business (Auguste et al. (2006) refer to the strategic options as 'defend' and 'grow').

When the product differentiation strategy is privileged, services are regarded as supplementary to the products. The strategic aim is to provide a better product offering than that of competitors, by means of differentiation (Treacy and Wiersema, 1993). For instance, customer support and after-sales services can be offered to provide a better reason to buy the product and to ensure future product sales. In this sense, services are developed and included as long as the objective is to support the sales of products - that is, 'a necessary evil' (cf. Kowalkowski et al., 2012). Despite a potentially heightened importance attributed to services, product differentiation is therefore an inherently goods-centric marketing strategy.

On the other hand, service focus is a different strategic path. Service focus aims to develop a distinct service business that can potentially be independent from the traditional 
product business (Raddats and Easingwood, 2010). For that reason, manufacturing firms, which operate under a service focus strategy, can offer services around an originating product (e.g. a maintenance contract that can be sold separately but is still anchored to the product), and product-independent services (e.g. process optimization and training services can be formulated based on the capabilities of the firm and sold independently from the product business). Typically, service focus strategies require more extensive interaction and collaboration between customer and supplier (Gebauer, Fleisch, and Friedli, 2005), and more emphasis on mutual construction of value-in-use (cf. Aarikka-Stenroos and Jaakkola, 2011). Such strategy changes the fundamental way in which manufacturing firms take action. As such, it can be seen as a strategic choice wherein service focus corresponds to what is valuable for the customer rather than what is necessary in order to differentiate the product portfolio (Kowalkowski et al., 2012). In fact, the service focus strategy is counter-intuitive for a business built on selling products. For example, when document management firm Xerox pursued such a service strategy, some big industrial customers went from having 50,000 to less than 25,000 Xerox-made machines (Shotter, 2012). Hence, a service focus strategy might be in partial conflict with the traditional product business (Gebauer and Friedli, 2007; Mathieu, 2001); therefore, the firm must be willing and able to cannibalize even its currently effective (product-related) capabilities (Kindström and Kowalkowski, 2014).

Table 2 illustrates the two distinct strategies, product differentiation or service focus. However, it remains unclear whether the form in which the market is understood has an effect on the selection of strategy. It is possible that one strategy fits the context better than the other strategy, depending on the form in which the market is understood. The next logical step is identifying sufficiently different types of representations that can be framed as a treatment for the quasi-experiment.

-Insert Table 2 around here-

\section{Method: Quasi-experiments enhancing case studies}


Because the most common research method in industrial marketing is case study research (Easton, 2010), case studies are the most common source of evidence demonstrating the significance of how firms conceive their markets (Azimont and Araujo, 2007; Biggemann et al., 2013; Rinallo and Golfetto, 2006; Harrison and Kjellberg, 2010). Therefore, findings in industrial marketing may benefit from replication when case studies and hypothesis-testing research are mutually complementary (LaPlaca, 2014). Analogies between case studies and experiments abound (Eisenhardt, 1989; Lee, 1989; Flyvbjerg, 2006). For instance, Lee (1989) describes how case studies could be framed as experiments following the same inductive thinking for testing a hypothesis grounded in previous theory. Flyvbjerg (2006) explains how both case studies and experiments benefit from 'hindsight', and Eisenhardt (1989) argues that problem definition and construct validation follow the same inductive logic.

Experiments can strengthen findings from case study research by a process of replication. In marketing, an experiment is a quantitative technique in which a treatment is tested for effects on a dependent variable, in search of cause-effect relationship (Sawyer, Worthing, and Sendak, 1979). A treatment is a stimulus that is manipulated to be independent from other variables. The treatment is applied to a group of people that is as homogeneous as possible, assuming that an effect could be reasonably attributed to the treatment. An experiment requires clearly identifiable treatments and controlled conditions. For example, an experiment that tests which packaging color sells more products should customize packages to be identical except for color, and other conditions-such as respondent demographic, product illumination levels, display location, and so on-should be controlled. The strength of experiments lies in isolating extraneous variables that are normally difficult to separate in natural settings (Mook, 1983).

Experiments are subject to concerns regarding internal validity (Croson, 2002), which reflects the extent to which causality can be inferred from a study, which depends upon minimizing systematic error. When an experiment cannot warrant full independence between variables, then it is called a quasi-experiment (Campbell and Stanley, 1963). A quasiexperiment is a type of research that has some features of experiments but not others - for example, a quasi-experiment may include a manipulated independent variable but no exhaustive controls, or it may include controls but lack fully independent variables. Bonoma (1985, p. 202) argued about tradeoffs of research in marketing, and explained that quasiexperiments can be used when "the opportunity for quantification is possible [...] provided 
that there is a body of prior theory upon which investigations can be structured for good deduction."

Because representations rely on interpretations, independence between variables cannot be guaranteed. Thus, any experimental design testing representations from case studies should be identified as a quasi-experiment. Market representations resulting from insights drawn from case studies originate empirically, using the same type of experimental thinking that is used in experimental design (Eisenhardt, 1989; Lee, 1989; Flyvbjerg, 2006). External validity of case studies can be strengthened by the internal validity of quasi-experiments, which have been criticized as being highly idealized (Croson, 2002).

\subsection{Hypothesis development}

In review, in order to test whether market representations influence strategy in industrial settings, two separate types of market representations were presented as a treatment: ostensive and performative market representations. The dependent variable is the selection of either service focus or product differentiation strategies. What follows frames the hypotheses about causal relationships between market representations and marketing strategies. The quasi-experiment is constructed as follows: (1) the stimulus is a business case introducing the respondent as the managing director of a medium-sized industrial firm; (2) two versions of the business case are similar in everything except in the market representations introduced by fictitious advisors; (3) the market representations differ based on either features of market structures (ostensive) or capabilities of the firm (performative); and (4) the selection of a marketing strategy - either product differentiation or service focus strategy -serves as the dependent variable.

The process of hypothesis development reflected the following line of thought. Assuming that ostensive market representations focus on the environment independently from the capabilities of the firm, the business case can be deconstructed as a rather conventional marketing situation where conventional marketing training is implemented as a prescription. Furthermore, given that (1) product-oriented strategies such as product differentiation are normative marketing strategies disseminated in marketing education at universities and business schools (cf. Jobber and Fahy, 2012; Kotler, 1967), and (2) theories influence managers' practices and worldviews (Ghoshal, 2005), marketing managers could consider normative marketing techniques in a conventional marketing situation. Therefore, we expect 
ostensive representations to support a product differentiation strategy rather than a service focus strategy.

H1. An ostensive market representation relates positively to a product differentiation strategy.

H2. An ostensive market representation relates negatively to a service focus strategy.

On the other hand, assuming that performative market representations focus on the capabilities of the firm to affect the environment, the business case could be deconstructed as a situation in which the firm should use any and all advantages available - that is, a situation in which a non-normative solution could better fit the firm. Studies of service business development in industrial firms report that many firms pursue service focus strategies and have learned to leverage their resource base and build distinctive service capabilities (Kindström and Kowalkowski, 2014; Ulaga and Reinartz, 2011). Therefore, we expect that a performative representation focusing on the capabilities of the firm would support a service focus strategy rather than a product differentiation strategy.

H3. A performative market representation relates negatively to a product differentiation strategy.

H4. A performative market representation relates positively to a service focus strategy.

\subsection{Stimulus development, homogeneity in the group, and manipulations}

\subsubsection{Stimulus development}

The stimulus took the form of a business case (Appendix 1) and was designed to follow the structure of a business case in a business-to-business setting, a format often used in MBA programs. A business case was selected for the following reasons: (1) marketing practitioners are familiar with the format because it is used often in business schools; (2) the case allows for more control to craft independent treatments; (3) third, the format allows for the selection 
of multiple routes of action; and (4) the case format allows the manipulation of the treatment as part of a narrative.

The business case was attached to a questionnaire and introduced a fictitious mediumsized manufacturer of industrial components that were used by the manufacturer's industrial customers to manufacture final products. The firm supposedly suffered from diminishing financial returns due to product commoditization. In response to diminishing returns, the firm developed an imaginary innovation with an application that was not self-evident given the firm's limited resources and capabilities. The selection of the strategy was designed as the dependent variable. The respondent had to decide which course of action the company should take given that the innovation could be either used to further differentiate the original product (i.e., a product-differentiation strategy), or commercialized in the form of a service (i.e., a service-focus strategy). Respondents were asked through an open-ended question to justify and explain their selection of either strategy.

Because the very idea of the method is to expand findings from case studies, no validated scales existed. All measures consisted of multi-item semantic differentiation-type scales ranging from 1 to 10 . For reliability concerns, two sets of items were used. The first items indicated the likelihood of choosing each strategy. The response format ranged from 1 (most unlikely) to 10 (most likely) for each of the options offered. The second set of items required the respondent to rank the options in the order that they would most likely choose: 1 for the main choice and 2 for the least preferred choice. An open-ended question was presented after the ranking, requiring the respondent to provide the reasons for selecting a strategy, to provide explanatory cues (Miles and Huberman, 1994).

\subsubsection{Group homogeneity}

An instrument was given to 143 students on their last year at a master's level program in marketing. The use of students as surrogate managers is justifiable in this exercise in order to maintain the homogeneity of the group, and because external validity comes from grounding the representations derived from case studies. Furthermore, business students solve business cases in a similar way to managers (Remus 1986; Henkens et al., 2009). The use of students is a trade-off because it is possible to manipulate a market representation while simultaneously adding group homogeneity. In contrast, while managers are more experienced, it is more difficult to claim group homogeneity because they differ in terms of work 
experience, company culture and history, industry, academic background, and demographics. Thus, the tradeoff is between external and internal validity.

\subsubsection{Experimental procedure}

Respondents were randomly allocated to the conditions. Each participant was presented with a business case containing the background of the industrial firm and the fictional situation. Respondents were instructed to read the scenario carefully and imagine themselves as the managing director of that firm. After reading the case, respondents answered questions assessing the likelihood that they would make a recommendation toward a marketing strategy, as well as questions about the case. Questions regarding manipulation check were included, as well as an open-ended question supporting the selection of the strategy. Double-checking the open-ended questions enabled identifying and coding mistakes where strategy selection conflicted with text supporting the opposing strategy.

\subsubsection{Manipulations}

Papers were shuffled and delivered when students entered the classroom. To assess that manipulations were successful, a question was included concerning the extent to which the information contained in the business case was actionable. The students who received a performative market representation were more likely to consider the information provided in business case actionable $(M=6.24)$ than the students who received an ostensive market representation $(M=4.36)$. A significant effect was apparent in the perception of the extent to which the information provided in the business case was actionable, at the $p<0.05$ level for the three conditions $[\mathrm{F}(1,141)=47, \mathrm{p}=<0.01]$. As such, it can be contended that the manipulation was successful.

\subsection{Hypothesis testing}

The results support $\mathrm{H}_{1}$ and $\mathrm{H}_{4}$. The first test is a categorical selection of product differentiation and service focus strategies in mutually exclusive terms. A Pearson chi-square test was used, and a causal relationship for $\mathrm{H}_{2}$ and $\mathrm{H}_{3}$ was found $[\chi 2(1, \mathrm{~N}=143)=11.9, \mathrm{p}$ $<.01]$. The test suggests that product differentiation was more likely with ostensive representations (58\%), and that a service focus was more likely with performative representations $(70 \%)$. 
The second test measured items that potentially co-exist on a 10-point scale. The two strategies could be considered equally feasible. The purpose was to eliminate the possibility of forced selection between items that were not sufficiently different. A t-test was used because items were intervals. A significant difference emerged again and supported $\mathrm{H}_{1}$ and $\mathrm{H}_{4}[t(141)=2.7, p<.01]$. The group exposed to a performative representation was more likely to follow a service focus $(M=7.2)$, than those exposed to ostensive representation ( $M$ $=6.1)$. Further, product differentiation has significant differences as well $[t(141)=3.1, p$ $<.01]$. The group exposed to an ostensive representation was more likely to follow a product strategy $(M=7)$ than the group exposed to a performative market representation $(M=5.8)$.

Scales were tested for independence $(\alpha<0.5)$ and correlated negatively $[r(141)=-.65, p$ $<.01]$, and then a MANOVA was used to test the inter-subject factor in order to assess the impact of representations and marketing strategy. An overall significant difference of the treatments was found (Wilk's $\lambda=0.93, p<.01)$ on both service focus $(\mathrm{F}=9.6, p<.01)$ and product strategy $(\mathrm{F}=7, p<.01)$. However, magnitude was not tested, because it was possible to rate both strategies equally. Magnitude was computed for those respondents who did not feel strongly about selecting one strategy over another. Approximately one third of the respondents $(34 \%)$ placed within 2 points of the options on the scale, indicating that both strategies fit the business case. Differences were significant $\left[\chi^{2}(1, \mathrm{~N}=143)=9.7, p<.01\right]$ only when comparing respondents who leaned strongly in favor of either product differentiation or service focus, but not when comparing respondents who felt that product differentiation and service focus strategies fit equally.

\subsection{Open-ended questions used for interpretative cues}

In order to add redundancy and cues for interpretation, the study included an open-ended question asking respondents to justify and explain their selection of either strategy, and a researcher coded the responses using human judgment (Perreault and Leigh, 1989). As suggested by Perreault and Leigh (1989), in order to increase reliability, a second researcher coded the answers independently, and the two researchers discussed their decisions in order to condense categories.

The resulting categorization included 17 reasons for respondents selecting either type of strategy. Only certain codes included enough responses to qualify for a test, but for those 
codes with enough repetitions, values were significantly different $(p<.05)$ according to the two-sided test of equality for column proportions. In other words, separate reasons were given to support privileging an industrial marketing strategy (see Table 3).

Insert Table 3 around here

For those who chose a product differentiation strategy, the reasons offered were related to the construction of a stronger core product offering (24\%), which is important for supporting the efforts of the sales team. Salespeople could integrate a more convincing offering, which would serve as competitive advantage against competitors (12\%). Some respondents found that a better market positioning $(17 \%)$ was consistent with such a strategy because it potentially differentiates the current product offering and command a higher price. In addition, respondents argued that a product differentiation strategy was necessary for securing the main revenue stream for the company (9\%). Therefore, the strategy was rationalized in terms of strengthening the existing offering, which is vitally important given the limited number of products and customers in medium-sized firms (Storey and Harlow, 2010).

Some respondents answered that the new service may even be sold to competitors through licensing, increasing sales and expanding the number of customers (23\%). A service focus strategy was appropriate to diversify revenue streams, which could strengthen the firm by reducing dependency on a single product (17\%). Further, respondents argued against augmenting the existing product because doing so could yield only temporary benefit and be easy for competitors to imitate; a service focus strategy could provide a more sustainable advantage over time (17\%). Respondents also justified choosing the strategy by pointing to stronger business relationships with existing customers (13\%). Therefore, the strategy was rationalized in terms of diversifying the current offering, which is vitally importance for reducing the risk associated with relying on a single offering. One reason for selecting a service focus was the perception that a service is more difficult to copy than a strengthened product. 


\section{Discussion and implications}

\subsection{Conceptual implications}

Industrial marketing scholars have theorized about a constructive dimension between market representations and the type of strategies that firms apply (Harrison and Kjellberg, 2010). This paper demonstrates that - at least in an ideal setting and under controlled conditions - the form in which market representations are formulated influences marketing strategy. Results indicate that multiple views of markets can exist, and that the study of these various views is relevant, because the form in which managers represent their markets constrains how firms invest their time and money.

The case used in the exercise was drawn from service management literature. Findings suggest that a service focus strategy is more likely when market representations are performative, and a product differentiation strategy is more likely when market representations are ostensive. Hence, the strategy selected can be attributed to the form in which marketing knowledge has been codified and taught. With an ostensive market representation, the business case appears to be a 'conventional market' where normative, mainstream marketing thought applies. In addition, when the market is perceived as static and not malleable, there is less room for innovative strategies. The ostensive representation highlighted market structures that appeared to be more difficult to change, so respondents opted for a stronger market position by strengthening their product offering (cf. Porter's [1985] outside-in view). On the other hand, findings suggest that when the resources and capabilities of the organization are considered, using performative market representations, a service focus is more likely to be selected. Rather than focusing on positional advantage over competitors, emphasis is placed on long-term advantages and stronger customer relationships. Such an approach resonates with a resource-based view of the firm, in which the firm can translate unique resources and distinct capabilities into innovative services, thereby expanding to novel market spaces (Kindström and Kowalkowski, 2014; Ulaga and Reinartz, 2011). Although it has been argued that service focus strategies are appropriate for manufacturing firms (e.g., Grönroos and Ravald, 2011), different firms choose very different service focus strategies, some of which resemble a product differentiation strategy, and some of which resemble a service focus strategy (Gebauer, 2008; Raddats and Easingwood, 2010). Our results indicate that market representations are a potential factor influencing the firm's espoused service strategy. 


\subsection{Methodological implications}

The present study makes two important methodological contributions to marketing research. First, it proposes that market representations can be used as treatments in quasiexperiments, since the method has provisions for semi-independence between variables. Market representations can become treatments as long as an existing corpus of theory shows enough differences. Second, we expand the parallel between case study research and experiments, thereby extending the method toolbox for marketing research, and responding to the call by LaPlaca (2014) to complement the descriptive research found in qualitative case studies.

This paper argues that quasi-experiments-empirical studies resembling experiments in many aspects but not with regards to either exhaustive controls or complete independence between treatments-can be used to replicate findings from case studies. The relevance for industrial marketing is that increasing the level of abstraction and proposing testable constructs could enhance findings from qualitative case study research, which often results in narratives. One of the main benefits of complementing case study research with quasi-experiments is that the combination offsets some of the intrinsic limitations of each method. The strength of quasiexperiments is high internal validity, but the trade-off is that quasi-experiments tend to be highly idealized, lacking a strong anchor in everyday marketing practice. On the other hand, the strength of case study research lies in the strong correspondence between the case and the manner in which firms really operate, but among the limitations are weak explanatory and predictive powers. Even if case study research is an established scientific method (Yin, 2009; Tsang, 2013) and the most common method in industrial marketing (Easton, 2010), it is mainly descriptive in nature. It is precisely by expanding the link between case studies and experiments that findings from industrial marketing may be strengthened with prediction and control.

\subsection{Managerial implications}

Managers benefit from understanding how representations affect the way they understand their markets, and how these market representations influence their decisions. By becoming aware of the power of representations, managers can be more critical and deliberate about how they form and deconstruct representations. Market representations are relevant for 
business decisions, and as such, managers apply a critical eye to whether a market representation fully considers the capabilities of the organization, or whether the structures represented are important in a particular market.

The second implication is the use of quasi-experiments in management. Experiments and quasi-experiments are associated with academic researchers and not typically used in management practice, but they can be applied in management practice as well, especially simulations. A simulation is a representation that is not anchored in reality (Baudrillard, 1984) and thus only exists virtually. Simulations are used for long-range planning, playing with scenarios in which a few crucial aspects of the market are modified. One example of this type of application is simulating the effect of an anticipated law in the market. Because that law is not yet fully implemented, no one really knows its full effects, but simulations can help researchers anticipate possible scenarios. The quasi-experiment method may be used in expert panels to identify possible consequences and courses of action. In this way, managers can isolate the simulations and identify potentially effective courses of action.

\subsection{Limitations and future research}

Because this paper introduces the application of a method to a new setting, several limitations can be expected, some of which offer fruitful avenues for research. Quasiexperiments have limitations by design and by implementation. A limitation by design is that representations used as treatments should be carefully selected, due to the controlled nature of quasi-experiments. If representations are not comparable at baseline, then the experiment may be biased. Another limitation is that of magnitude, because even when an effect can be identified, its magnitude cannot be measured. The purpose of a quasi-experiment is to isolate exogenous variables, such as manager experience, or industrial setting. Without other explanatory variables, the magnitude of the effect cannot be estimated directly, so it is advisable to conduct multiple studies. Future research should use quasi-experiments validation order to validate case studies. Including quasi-experiments in business research can make the research design more robust.

A limitation by implementation is the practical identification of a homogeneous group for testing hypothesis. Consider that testing advertising requires only the identification of the demographic and psychographic segment of the public that is considered the target audience for advertising. In industrial marketing, business scholars refer to managers - a group with 
specialized training and expertise that is scarce not only in number, but also in their own willingness to devote time to research. Using quasi-experiments in industrial marketing requires a degree of compromise. In this study, we used marketing students in the final year of an advanced master's-level course as proxies for managers. The use of students was intended to increase construct validity using a homogeneous group in which managerial experience could be controlled (Mook, 1983); it remains unclear whether master's-level students in a business school are anything like actual business managers, given their lack of experience. Although Ghoshal (2005) argues that the theories thought at business schools has significant influence on the practice of management, future research should validate whether marketing education in business schools actually corresponds with how industrial managers behave. Therefore, validating a correspondence between industrial managers and business students is crucial for further development of quasi-experiments in industrial marketing.

A second limitation by implementation is the development of scales (Durvasula, Sharma, and Carter, 2012). Because representations derived from case studies are unlikely to have validated scales, reliability tests are particularly important for ensuring that a researcher is measuring what needs to be measured (Peterson, 1994). The study described this paper did not use validated scales, which is a limitation. However, future research can develop scales for the most important constructs in industrial marketing, so that others can use them. Overall, given what is known about relationship marketing, service focus, product differentiation, and value creation strategies, researchers still do not have a codified list of strategies for uncovering whether any firm qualifies to actually carry them out.

While these limitations must be kept in mind when considering our conceptual, methodological, and managerial implications, our findings provide new insights and greater familiarity with quasi-experiments in industrial marketing, which we hope stimulate future research in this promising, underresearched domain.

\section{Conclusions}

A quasi-experiment tested whether market representations influence marketing strategy. A comparison of service focus and product differentiation marketing strategies was conducted according to the treatment of two types of market representations: market representations that focus on firms as autonomous agents capable of shaping their 
environment (i.e., performative); and market representations that focus on structures and other constraining aspects of markets (i.e., ostensive). These two types were presented as treatments. Results support existing theory in industrial marketing (Harrison and Kjellberg, 2011), indicating that there is a constructive dimension for market representations (Rinallo and Golfetto, 2006). Further, the form in which a firm represents its market affects the selection of a marketing strategy - at least under idealized conditions - and thus, a service focus strategy is more likely when market representations are performative, and a product differentiation strategy is more likely in the context of an ostensive market representation. The quasi-experiment presented evidence that a service focus strategy is more likely to be adopted when market representations are destabilizing and dynamic, as opposed to product differentiation strategy, which is more likely chosen when market representations are indicative and stable.

\section{Acknowledgements}

The authors would like to thank Maria Holmlund, and Chris Raddats for their trenchant comments on previous versions of this article.

\section{Declaration of conflicting interests}

The authors declared no potential conflicts of interest with respect to the research, authorship, or publication of this article.

\section{References}

Aarikka-Stenroos, L., \& Jaakkola, E. (2012). Value co-creation in knowledge intensive business services: A dyadic perspective on the joint problem solving process. Industrial Marketing Management, 41(1), 15-26.

Araujo, L. (2007). Markets, market-making and marketing. Marketing Theory, 7(3), 211-226.

Auguste, B. G., Harmon, E. P., \& Pandit, V. (2006). The right service strategies for product companies. McKinsey Quarterly, 1, 40-51.

Austin, J. L. (1975). How to Do Things With Words (2nd ed.). Urmson J. O., Sbisa M. (Eds.), Cambridge, MA: Harvard University Press.

Azimont, F., \& Araujo, L. (2007). Category reviews as market-shaping events. Industrial Marketing Management, 36(7), 849-860. 
Azimont, F., \& Araujo, L. (2010). The making of a petrol station and the "on-the-move consumer": Classification devices and the shaping of markets. Industrial Marketing Management, 39(6), 1010-1018.

Baudrillard, J. (1994). Simulacra and Simulation [Simulacres et Simulation] (S. Glaser Trans.). (First published in 1981 ed.). Michigan, USA: University of Michigan Press.

Bernhardt, D. C. (1994). "I want it fast, factual, actionable" - tailoring competitive intelligence to executives' needs. Long Range Planning, 27(1), 12-24.

Biggemann, S., Kowalkowski, C., Maley, J., \& Brege, S. (2013). Development and implementation of customer solutions: A study of process dynamics and market shaping. Industrial Marketing Management, 42(7), 1083-1092.

Bonoma, T. V. (1985). Case research in marketing: Opportunities, problems, and a process. Journal of Marketing Research, 22(2), 199-208.

Callon, M. (1998). Introduction: The embeddedness of economic markets in economics. In M. Callon (Ed.), The Laws of Markets (pp. 1-57). Oxford, UK: Blackwell Publishers.

Campbell, D. T., Stanley, J. C., \& Gage, N. L. (1963). Experimental and quasi-experimental designs for research Houghton Mifflin Boston.

Croson, R. (2002). Why and how to experiment: Methodologies from experimental economics. University of Illinois Law Review, 921-946.

Day, G. S. (2002). Managing the market learning process. Journal of Business \& Industrial Marketing, 17(4), 240-252.

Day, G. S., \& Nedungadi, P. (1994). Managerial representations of competitive advantage. Journal of Marketing, 58(2), 31-44.

Deshpande, R., \& Zaltman, G. (1982). Factors affecting the use of market research information: A path analysis. Journal of Marketing Research, 19(1), 14-31.

Diaz Ruiz, C. A. (2013). Assembling market representations. Marketing Theory, 13(3), 245261.

Eisenhardt, K. M. (1989). Building theories from case study research. Academy of Management Review, 14(4), 532-550.

Finch, J., \& Geiger, S. (2011). Constructing and contesting markets through the market object. Industrial Marketing Management, 40(6), 899-906.

Flyvbjerg, B. (2006). Five misunderstandings about case-study research. Qualitative Inquiry, 12(2), 219-245.

Ford, D., \& Håkansson, H. (2006). IMP - some things achieved: Much more to do. European Journal of Marketing, 40(3), 248-258. 
Gardner, B. B., \& Levy, S. J. (1955). The product and the brand. Harvard Business Review, 33(2), 33-39.

Gebauer, H. (2008). Identifying service strategies in product manufacturing companies by exploring environment-strategy configurations. Industrial Marketing Management, 37(3), 278-291.

Gebauer, H., Fleisch, E., \& Friedli, T. (2005). Overcoming the service paradox in manufacturing companies. European Management Journal, 23(1), 14-26.

Ghoshal, S. (2005). Bad management theories are destroying good management practices. Academy of Management Learning \& Education, 4(1), 75-91.

Grazzini, F. (2013). How do managers make sense of strategy? European Business Review, 25(6), 484-517.

Grönroos, C., \& Ravald, A. (2011). Service as business logic: Implications for value creation and marketing. Journal of Service Management, 22(1), 5-22.

Hagberg, J., \& Kjellberg, H. (2010). Who performs marketing? Dimensions of agential variation in market practice. Industrial Marketing Management, 39(6), 1028-1037.

Håkansson, H., \& Ford, D. (2002). How should companies interact in business networks? Journal of Business Research, 55(2), 133-139.

Harrison, D. (2012). Being a networking firm on a day-to-day basis: Customer and supplier routines in the global fish case. The IMP Journal, 6(3), 267-276.

Harrison, D., \& Kjellberg, H. (2010). Segmenting a market in the making: Industrial market segmentation as construction. Industrial Marketing Management, 39(5), 784-792.

Henkens, K., Van Solinge, H., \& Cozijnsen, R. (2009). Let go or retain? A comparative study of the attitudes of business students and managers about the retirement of older workers. Journal of Applied Social Psychology, 39(7), 1562-1588.

Jobber, D., \& Fahy, J. (2012). Foundations of Marketing (4th ed.). Berkshire, UK: McGrawHill Education.

Kindström, D., \& Kowalkowski, C. (2014). Service innovation in product-centric firms: A multidimensional business model perspective. Journal of Business \& Industrial Marketing, 29(2), 96-111.

Kjellberg, H., \& Helgesson, C. (2006). Multiple versions of markets: Multiplicity and performativity in market practice. Industrial Marketing Management, 35(7), 839-855.

Kjellberg, H., Storbacka, K., Akaka, M. A., Chandler, J., Finch, J., Lindeman, S., et al. (2012). Market futures/future markets: Research directions in the study of markets. Marketing Theory, 12(2), 219-223. 
Kotler, P. (1967). Marketing Management: Analysis, Planning and Control. Englewood Cliffs, NJ: Prentice-Hall.

Kowalkowski, C., Kindström, D., Alejandro, T. B., Brege, S., \& Biggemann, S. (2012). Service infusion as agile incrementalism in action. Journal of Business Research, 65(6), $765-772$.

LaPlaca, P. (2014). Advancing industrial marketing theory: the need for improved research. Journal of Business Market Management, 7(1), 284-288.

Lee, A. S. (1989). Case studies as natural experiments. Human Relations, 42(2), 117-137.

Levy, S. J. (1959). Symbols for sale. Harvard Business Review, 37, 117-124.

McLoughlin, D., \& Horan, C. (2002). Markets-as-networks: Notes on a unique understanding. 55(7), 535-543.

Miles, M. B., \& Huberman, A. M. (1994). Qualitative Data Analysis: An Expanded Sourcebook. Sage Publications, Incorporated.

Mook, D. G. (1983). In defense of external invalidity. American Psychologist, 38(4), 379387.

Myers, J. H., \& Tauber, E. (1977). Market Structure Analysis. Chicago, US: American Marketing Association.

Normann, R. (2001). Reframing business: When the Map Changes the Landscape. Chichester, England: John Wiley \& Sons, Ltd.

Peteraf, M. A. (1993). The cornerstones of competitive advantage: A resource-based view. Strategic Management Journal, 14(3), 179-191.

Porter, M. E. (2008). The five competitive forces that shape strategy. Harvard Business Review, January, 79-93.

Prahalad, C., \& Hamel, G. (2005). The core competence of the corporation. In N. J. Foss (Ed.), Resources, Firms, and Strategies: A Reader in the Resource-Based Perspective (First published in 1997 ed., pp. 235-256). New York: Oxford University Press.

Raddats, C., \& Easingwood, C. (2010). Services growth options for B2B product-centric businesses. Industrial Marketing Management, 39(8), 1334-1345.

Remus, W. (1986). Graduate students as surrogates for managers in experiments on business decision making. Journal of Business Research, 14(1), 19-25.

Rinallo, D., \& Golfetto, F. (2006). Representing markets: The shaping of fashion trends by French and Italian fabric companies. Industrial Marketing Management, 35(7), 856-869.

Sawyer, A. G., Worthing, P. M., \& Sendak, P. E. (1979). The role of laboratory experiments to test marketing strategies. Journal of Marketing, 43(3), 60-67. 
Shotter, J. (2012). UK groups lag behind in adding services. Financial Times, May 29.

Stern, B. B. (2004). Introduction: The problematics of representation. In B. B. Stern (Ed.), Representing Consumers: Voices, Views and Visions (First edition printed in 1998 ed., pp. 1-24). London, UK: Routledge.

Storbacka, K., \& Nenonen, S. (2011). Scripting markets: From value propositions to market propositions. Industrial Marketing Management, 40(2), 255-266.

Treacy, M., \& Wiersema, F. (1993). Customer intimacy and other value disciplines. Harvard Business Review, 71, 84-84.

Ulaga, W., \& Reinartz, W. J. (2011). Hybrid offerings: How manufacturing firms combine goods and services successfully. Journal of Marketing, 75(6), 5-23.

Vanharanta, M., \& Easton, G. (2010). Intuitive managerial thinking; the use of mental simulations in the industrial marketing context. Industrial Marketing Management, 39(3), $425-436$.

Varey, R. (2010). The economics basis of marketing. In M. Saren, \& M. J. Baker (Eds.), Marketing Theory: A Student Text (2nd ed., pp. 101-120). London, UK: SAGE.

Wittgenstein, L. (1953). Philosophical Investigations [Philosophische Untersuchungen] (G. Anscombe Trans.). Blackwell Publishing. 
TABLE 1

Dimension of interest: product-oriented vs. service-oriented strategy

Product differentiation

Protecting the product business

Aim

by avoiding commoditization

A better offering than that of

Justification competitors by means of differentiation

Service focus

Enable value-in-use through resource integration in reciprocal relationships

An offering which corresponds to what is valuable for a customer

Services are provided as add-ons Both product-related (e.g. (either bundled or separately sold) to support the sales of a product maintenance), and productindependent services (e.g. process optimization) 
TABLE 2

Treatment: types of market representations

\begin{tabular}{|c|c|c|}
\hline \multicolumn{2}{|r|}{ Ostensive } & Performative \\
\hline Type & $\begin{array}{l}\text { Concise and descriptive: coherent } \\
\text { snippets encapsulating defining } \\
\text { aspects of the market }\end{array}$ & $\begin{array}{l}\text { Dynamic and instrumental: actionable } \\
\text { information linked to the capabilities } \\
\text { of the actor }\end{array}$ \\
\hline Object & $\begin{array}{l}\text { Structures: recurrent patterns } \\
\text { constraining options }\end{array}$ & $\begin{array}{l}\text { Agencies: autonomous agents capable } \\
\text { of shaping their environment }\end{array}$ \\
\hline Purpose & $\begin{array}{l}\text { Learning: information processing } \\
\text { and accumulation of knowledge }\end{array}$ & $\begin{array}{l}\text { Doing: actionable missions punctuated } \\
\text { in time and space }\end{array}$ \\
\hline \multicolumn{3}{|c|}{$\begin{array}{c}\text { TABLE } 3 \\
\text { Key reasons for selecting marketing strategy }\end{array}$} \\
\hline \multicolumn{2}{|c|}{ Product differentiation } & Service focus \\
\hline \multicolumn{2}{|c|}{$\begin{array}{l}\text { Secure the main stream of income by } \\
\text { offering a stronger core product offering }\end{array}$} & $\begin{array}{l}\text { ell the service to competitors through } \\
\text { licensing }\end{array}$ \\
\hline \multirow{2}{*}{\multicolumn{2}{|c|}{$\begin{array}{c}\text { Create a more convincing offering for the } \\
\text { sales team } \\
\text { Differentiate and achieve better market } \\
\text { positioning }\end{array}$}} & $\begin{array}{l}\text { Diversify revenue streams to reduce } \\
\text { endency on a single (product) offering }\end{array}$ \\
\hline & & $\begin{array}{l}\text { eve a more sustainable business position } \\
\text { over time }\end{array}$ \\
\hline \multicolumn{2}{|c|}{ Secure the main revenue stream of the firm } & $\begin{array}{l}\text { nild closer relationships with existing } \\
\text { customers }\end{array}$ \\
\hline
\end{tabular}




\begin{abstract}
APPENDIX 1
(Performative version; Indication not presented)

\section{Imagine this:}

You are the managing director of a company called Orlanda Inc. (Orlanda), a family-owned company in operation for more than 100 years. Orlanda is a medium-sized industrial manufacturing company producing optical sub-components. These devices are made of an optic lens and a controlling element, which determines the amount of light that passes through the lens. Optical sub-components cannot be used alone, and therefore, are sold to larger manufacturers that assemble all kind of products, such as: microscopes, cameras, or endoscopes. Orlanda's sub-components are of sufficient quality to fit standards created by the buyers.
\end{abstract}

The problem is that even when meeting quality standards, optical sub-components manufactured by Orlanda are very similar to those produced by a dozen other producers around the world. Due in part to this similarity, optical sub-components must be sold at a cheaper price every year. For the fourth year in a row, the company revenues have steadily decreased. With diminishing profitability, the company is in trouble.

Hope emerges when a group of Orlanda's engineers invent and patent a new controlling device for the lens. This innovation uses more advanced electronics, allowing subcomponents to recognize shapes passing through the lens. However, it is unclear how to use this innovation. Your advisors gathered the following market report:

- Orlanda depends too much on only a few customers, because five large manufacturers companies buy $75 \%$ of the global production.

- Orlanda needs to find a way around the standards that buyers have created for producers, because optical sub-components are, in practice, all the same.

- Orlanda has the opportunity to reach end-customers and not only sell to intermediaries. The industry now is divided between producers, such as Orlanda, and product manufacturers.

- Orlanda needs new offers to enhance its negotiating position, because oftentimes, buyers enforce steep discounts. 
- Orlanda can pitch a different offer because management has had a solid relationship with competitors and buyers for decades now. They all meet annually at the industry convention.

- Orlanda is constrained by current negotiation practices, because orders are placed on a yearly basis for the production that buyers will require in the following period.

- Orlanda's sales team can initiate new projects, because only top management conducts key negotiations.

- Using this information, you are asked to decide between the two following actions about what to do with the initiative developed and patented by Orlanda. Both initiatives have been evaluated and will require similar investments, and will yield similar financial returns:

- Offer the innovation as a service. Because of the many possible applications, Orlanda can upgrade, for a fee, any existing product with the new controlling device. The service offered by Orlanda will allow others to upgrade their own products assembled with the optical sub-components produced by any company. Further, customers can send their existing products to Orlanda and receive an upgraded product. This service can be treated as a different business unit.

- Differentiate Orlanda's offer. The new innovation will be used only on Orlanda's own existing production in order to differentiate its product clearly within the industry. Orlanda's sub-components will gain a competitive advantage which, arguably, can provide more convincing arguments to close a sale.

\section{Please answer the questions on the following page.}

(Ostensive version; Indication not presented)

\section{Imagine this:}

You are the managing director of a company called Orlanda Inc. (Orlanda); a family-owned company in operation for more than 100 years. Orlanda is a medium-sized industrial manufacturing company that produces optical sub-components. These devices are made of an optic lens and a controlling element that determines the amount of light which passes through the lens. Optical sub-components cannot be used alone, so they are sold to larger manufacturers that assemble all kinds of products, such as: microscopes, cameras, or 
endoscopes. Orlanda's sub-components are of sufficient quality to meet standards created by the buyers.

The problem is that even matching quality standards, optical sub-components manufactured by Orlanda are very similar to those produced by a dozen other producers around the world. Due in part to this similarity, optical sub-components must be sold at a cheaper price every year. For the fourth year in a row, the company's revenues have steadily decreased. With diminishing profitability, the company is in trouble.

Hope emerges when a group of Orlanda's engineers invent and patent a new controlling device for the lens. This innovation uses more advanced electronics, allowing subcomponents to recognize shapes passing through the lens. However, it is unclear how best to use this innovation. Your advisors gathered the following market report:

- The industry is clearly divided between producers, such as Orlanda, and product manufacturers.

- The industry is well-established. Five large manufacturers companies buy $75 \%$ of world's production.

- Cost reductions are important for buyers, and steep discounts are often negotiated.

- Innovation in this industry is very rare, because buyers have settled on standards that producers must meet.

- The managers of all competitors and buyers have known each other for several years; they all meet annually at the industry convention.

- Orders are placed on a yearly basis for the production that buyers will require in the following period.

- While the producer's sales team manages the daily communications, buyers enforce key negotiations only with top management.

Using this information, you are asked to decide between the two following actions about what to do with the initiative developed and patented by Orlanda. Both initiatives have been evaluated and will require similar investments, and will yield similar financial returns:

- Differentiate Orlanda's offer. The new innovation will be used only on Orlanda's own existing production in order to differentiate clearly within the industry. Orlanda's subcomponents will gain a competitive advantage which, arguably, can provide more convincing arguments to close a sale. 
- Offer the innovation as a service. Because of the many possible applications, Orlanda can upgrade, for a fee, any existing product with the new controlling device. The service offered by Orlanda will allow others to upgrade their own products assembled with the optical sub-components produced by any company. Furthermore, customers can send their existing products to Orlanda and receive an upgraded product. This service can be treated as a different business unit.

(Thanks for the attention, please answer the questions in the following page...) 


\section{APPENDIX 2}

\section{Please answer the following...}

1. Please think about the two possible courses of action. How likely or unlikely are you to choose either of the following options:

Use the coating only on Orlanda's own products to provide a differentiation within the industry.

\begin{tabular}{|l|l|l|l|l|l|l|l|l|l|l|l|}
\hline Most unlikely & 1 & 2 & 3 & 4 & 5 & 6 & 7 & 8 & 9 & 10 & Very Likely \\
\hline
\end{tabular}

Offer the coating as a service, so that anybody owning a product with an optical subcomponent can have it enhanced by Orlanda.

\begin{tabular}{|l|l|l|l|l|l|l|l|l|l|l|l|}
\hline Most unlikely & 1 & 2 & 3 & 4 & 5 & 6 & 7 & 8 & 9 & 10 & Very Likely \\
\hline
\end{tabular}

2. If you were to choose only one option, which option would you choose? (please choose only one option)

Use the innovation as a new service

Use the innovation for differentiation

3. Why did you choose this option as the best course of action for Orlanda? What were your reasons? 
4. Where do you think the market report falls on the following scales?

\begin{tabular}{|c|c|c|c|c|c|c|c|c|c|c|c|}
\hline Informative & 1 & 2 & 3 & 4 & 5 & 6 & 7 & 8 & 9 & 10 & Actionable \\
\hline Firm oriented & 1 & 2 & 3 & 4 & 5 & 6 & 7 & 8 & 9 & 10 & Market oriented \\
\hline Incredible & 1 & 2 & 3 & 4 & 5 & 6 & 7 & 8 & 9 & 10 & Credible \\
\hline Useless & 1 & 2 & 3 & 4 & 5 & 6 & 7 & 8 & 9 & 10 & Useful \\
\hline Static & 1 & 2 & 3 & 4 & 5 & 6 & 7 & 8 & 9 & 10 & Dynamic \\
\hline General & 1 & 2 & 3 & 4 & 5 & 6 & 7 & 8 & 9 & 10 & focused \\
\hline Bad & 1 & 2 & 3 & 4 & 5 & 6 & 7 & 8 & 9 & 10 & Good \\
\hline
\end{tabular}

5. Regarding the case in general, where do you think the case falls on the following scales:

\begin{tabular}{|l|l|l|l|l|l|l|l|l|l|l|l|}
\hline Not credible & 1 & 2 & 3 & 4 & 5 & 6 & 7 & 8 & 9 & 10 & Credible \\
\hline Boring & 1 & 2 & 3 & 4 & 5 & 6 & 7 & 8 & 9 & 10 & Interesting \\
\hline
\end{tabular}

